\title{
Migration And Economic Changes: Sociological Analysis on the Contributions of Bugis Ethnic for the Economy of Kupang
}

Bacotang

\author{
Abustam \\ Pewennari Hijjang \\ Darman Manda
}

Universitas Negeri Makassar, JIn. Bonto Langkasa Kampus Gunung Sari Baru 90233, Makassar, South Sulawesi Indonesia; bacotang_nur@yahoo.co.id, idrus@gmail.com,aweunhas@yahoo.com,darmanmanda.ppsunm@yahoo.co.id

\section{Doi:10.5901/mjss.2016.v7n2s1p147}

\section{Abstract}

This study aims at analyzing the migration stages and mechanism of the Bugis ethnic to Kupang and the contributions of Bugis ethnic for the economy of Kupang. The research approach used a phenomenological approach which is one kind of qualitative research. The data were collected by participants' observation to determine the essential phenomenon and the participation in life experiences (Creswell, 2009). The results showed: (1) The migration process of Bugis ethnic to Kupang showed that the departure of Bugis ethnic to Kupang was because of economic factors and invitation of a family who had already migrated to Kupang, (2) contribution of Bugis ethnic to the economy of Kupang, the results showed that: Bugis ethnic contributed to the economy of Kupang, especially in the development of traditional markets, market tax receipts, land and buildings tax revenues, tax revenue of building permit, tax revenue of a business license, business license receipts, and the development of Kupang.

Keywords: Migration, Bugis ethnic, economic contribution.

\section{Introduction}

Indonesia is an archipelago country consisting of thousands small and large islands and the unusual population allow migration from one island to another or migration from one city to another city in Indonesia. Kupang is one of the most cities with migrants from other areas such as Bugis, Javanese, Padang, Chinese and local migrants from the district of Southeast Nusa.

The development and change of Kupang creates the rate of population growth due to migration with the total population: 349450 inhabitants, and the area is 18027 hectares. Kupang is a city with heterogeneous population consists of various ethnic and sub-ethnic, namely: (1) Timor (Original) 104 371, (2) Rote 59 593, (3) Sabu 41 493, (4) Sumba 9356, (5) Flores 29 074, (6) Alor 19 378, (7) Ende 5127, (8) Bugis ethnic 6652, (9) Java 19 742, (10) Others 41 453, BPS Kupang (2012). Source: www.kupangkota.go.id, accessed gth September, 2013 at 9:55 AM).

In relation with the precision above, the austerity in understanding the interaction patterns, relationships, adaptation of Bugis ethnic group in a new region in the middle of the local ethnic community of Kupang as the host city is needed to determine the direction of policy and the proper guidance in their involvement efforts in establishment moves, especially in Kupang. But the economic development of Bugis ethnic migrants in Kupang is very rapidly from various sectors, especially in traditional markets, fishermen, businessmen. It is not known certainly the extent of involvement or the contribution of Bugis ethnic to the economy of Kupang, particularly in local revenue (Pendapatan Asli Daerah), the labor absorption of native ethnic who contribute to the development of Kupang. It is important to be studied in depth.

\subsection{Theory of Migration and Social Change}

According to Mantra (1999) the population mobility can be distinguished between vertical and horizontal population mobility. Vertical population mobility is often called as a status change such as changes in employment status. Horizontal I geographical population mobility is population motion (movement) that crosses the area borders to get to other area in a specific time period. 
According to the study of Abustam (1989), one of the problems in the study of population movement / migration is the absence of a standard restriction on movement of people or the types. The restrictions of the research involve dimensions of time and space for example, migration from one place to another place or migration from island to another.

Migration theory originally introduced by Ravenstein (1885) in Wirawan (2006) that migration is the movement of people to settle from one place to another and surpass the area or political boundaries or the borders of other countries. Extensively, migration is actually in a global change in the economic, social, cultural and political.

Furthermore, the theory is used as the basic study of other researchers Lee (1970) and Wirawan (2006). Both researchers said that the main motive that causes a person to perform the migration is economic reason.

Mantra (1999), mentioned that some theories revealed why people do mobility namely, the theory of needs and stress. Every individual has some kind of economic needs, social, cultural, and psychological. If the demand is greater and cannot be met, the stress will be greater. When the stress already exceeds the limit, then someone will move to other places that can fulfill needs. This migration theory development is known as the model of stress-threshold or place-utility.

In addition, the concept of choice theory as Becker (1968), in Wirawan (2006), is also used to determine the person's motivation in deciding to work abroad. In this case, the individual is considered as a social being rational in determining the choice. Generally, individuals will apply the concept of economic principles to choose the best alternative or some of the greatest benefits and disadvantages or the smallest risks.

In relation with migration and social change, Sztompka (1993), found: migration and social changes covers certain systems in different periods, whereas the basic concepts of social change is the difference studies should be done at a different time with observation in the same social system. It indicates that in a study changes that occur in the community, the study of the changes can be assessed in the same context but in different time and place.

In the research of Lineton (1975) cited in Abustam (1989), discussed that the migration patterns of the Bugis Pasompe "Ugi" (Bugis nomads) to various areas in Indonesia, including East Kalimantan, West Kalimantan, South Kalimantan, Tanjung Priok, Jambi and the Riu. Pasompe "Ugi" is not just leaving Tana Ugi (Bugis area) because of dissatisfaction with social cultural and political system at that time, but also because of economic reasons to develop trade in the sea.

Bourdieu (2000) cited in Turner (2012) Economy Sociology focuses on network approach, economic and social construction, this focus used concepts of habitus, sphere, interest and capital. Bourdieu argued that how people live their lives as part of the economy to struggle with and against the existing economic structure.

Gronovetter (1982), social capital is one of alternatives to overcome poverty, health education, and the willingness of economic capital at the household level. According to Gronovetter, contribution of social capital is comparable with human capital. It indicates that non-physical capital is able to match with the physical lieutenant.

According to Polanyi et al (1968) Granovetter (1982), anthropological and sociological analysis emphasizes the sustainability of the market in patterns of social organization and cultural significance, namely, economic behavior is not analyzed as a stand-alone human activity, but as inseparable from a wide variety of social, political and cultural, behavioral, institutions, and beliefs. An economic action has a strong delay in the context of social networks.

Referring to Geetz study (1977), about the market economy is an institution at once a way of life, a common style of economic activities which includes many aspects. The market is an entity that is not merely moving and sustaining people economy to meet the sellers and buyers. The market has more complex responsibility and functions.

According to Endan Rudiatin (2012) market economy refers to the exchange with organized principle with particular principle such as price, demand and supply that create the transaction. Market in sociology can also refer to the specific social relationships and specific framework through the role of economic transactions. The first market is the network processes and economic transactions without a specific location or boundaries of space for the entire transaction.

Tamar (2007), the core culture of the Bugis is "siri" and "pesse". "Siri" has double meaning like a coin, and also means "shame" and the other side means "dignity" in psychology which means "self-respect". "Siri" is individuality value owned by Bugis people to achieve the results that can be expected. "Pesse" means tolerant to others in family, relatives and the community; it is the value of solidarity that exists within the Bugis to adapt with the social environment.

The creation of compound community in a city, like the description of Furnival (2009), compound economy provides opportunities to the presence of diversity and the economic activity gives effect to the social relations.

Meanwhile, Castells (1976), equalize urbanization as modernization and modern society is equal with the industrial capitalist society, outside of the reality of urban development in third world countries.

According Tirto Sudarmo (1993), the trading strategy of Bugis ethnic in Samarinda as distributor of the daily demand of society, when people need rice, Bugis traders bring rice commodity from Sout Sulawesi. 


\subsection{Assessing Relevant Research Accomplished}

Lineton (1975), found about the migration patterns of the Bugis: Pasompe Ugike various regions in Indonesia, including East Kalimantan, South Kalimantan, Tanjung Priok, Riu, Jambi. The result showed that the main factor of pasompe is dissatisfaction of cultural and political social system at that time, but also for economic reasons. In the research of Tamar (2007), the Bugis ethnic as a businessman has been known since before independence, despite the ebb and flow, but its success to be in national scale entrepreneurs cannot be denied. The success is inseparable from the local wisdom values of Bugis culture itself, the work ethic.

\section{Research Method}

\subsection{Paradigm Study, Type and approaches Research}

This study aims at describing and analyzing the migration of ethnic Bugis and social change from the origin to the destination. Furthermore, summoning the migration and social change of Bugis ethnic and contributing to the economy of Kupang. Therefore, the approach in this study is sociological approach.

The research approach above used a phenomenological approach which is one kind of qualitative research. The data were collected by participant observation to determine the essential phenomena of participation in life experiences (Creswell, 2009).

Qualitative approach used in this study taking into account that this study reveals a subjective human perception, in this case the migrants of Bugis ethnic in Kupang as research objects. Collected and obtained data of research subjects were oral or written statements, the perception of expression, subject observation atmosphere which is observed carefully.

\subsection{Location research}

The three villages namely, Naikoten I, Fatu Besi Oeba, and Oesapa are the majority of Bugis ethnic who lived and conducted business activities and trade. Before discussing the three villages, it is important to discuss Kupang city in general. Kupang city is located on the western tip of Timor Island, the location is not also near from the State of East Timor, but it is also dealing directly with North Australia. This condition puts Kupang as the gateway to the south of the Republic of Indonesia. This strategic position allows Kupang future will be the best choice as a gateway entrance / exit (Entry and Exit Gate) people, trade flow of goods / services, the current local, regional, national or international. Source: http: //www.petantt.com/kota-kupang. Accessed on 17th March, 2015.

\subsection{The history of the formation of the city of Kupang}

The history of the formation of the city of Kupang: The name of Kupang is derived from the word Lai Kopan (Nai Kopan) is the name of a king who ruled the city of Kupang before the Portuguese arrived in Kupang. In 1486, Timor Island has 12 harbour cities which are often visited by traders from western region of Indonesia to seek sandalwood, but the twelve cities are not mentioned by name. One of the cities is from the port city located on the strategic coast in the west of Timor Island. The city is known today by the name "Kupang," the city currently consists of six sub-districts namely, Alak, Maulafa, Oebobo, Kota Raja, Kelapa Lima, and the Kota Lama, and 51 villages, special locations in this research are three villages, namely Naikoten I, Oesapa, and the Fatubesi Oeba. Source: www.kupangkota.go.id, accessed 9 ${ }^{\text {th }}$ September, 2013 at 9:55 AM).

Kupang wide and geographical conditions, extension: 18027 ha, geographical conditions are topography highs above sea level in the south with a height of $100-350 \mathrm{~m}$, the lowest area above sea level in the north with a height of 0-50 $\mathrm{m}$ Level of average slope 15 percent. The formation of geologi ground consists of a hard material and non-volcanic materials. Mediterranean / rencinal / liotsol materials in District Alak, Maulafa, Oebobo, Kota Raja, Kelapa Lima and the Kota Lama. (www.kupangkota.go.id.) Accessed 9th September 2013, at 9:55 AM).

Geographic and Administrative boundaries: Geographical Limits: 10036 '14 "- 100 39' 58" South Latitude 123032 '23 "- 1230 37' 01" East Longitude. Administrative limits: East: District of Central Kupang, Kupang Regency West: District of West Kupang, Kupang Regency North: Kupang Bay South: Nekamese District and Sub-District of Taebenu, Kupang regency. Source: http: //www.petantt.com/kota-kupang/accessed 17th March, 2015

The results of this study outline the findings or results of interviews with informants in the field. The results of these 
interviews aimed to obtain data about the migration process of Bugis ethnic, economic development of Bugis ethnic, contribution of Bugis ethnic to local etnic and the economy of Kupang.

\section{Results and Discussion}

\subsection{Migration Process}

Research on the stages and mechanism of migration of Bugis ethnic from South Sulawesi to Kupang, through various processes or stages through which the migrants. Stages, namely preparation of the departure of capital, set off with the first successful family in the city of Kupang, the experience of friends who have migrated in Kupang, and invited by friends. There are several theories stating why someone takes decisions mobility or migration, including the theory of need and stress. Every individual has a need to be met, such as the need for economic, social, political, and psychological. The level of stress experienced by individuals is inversely related to the proportion of fulfillment.

There are two results of stress, namely when the stress level of people is low, then a man will not make the shift. A man remained in the area of origin and the need to adjust the existing environmental conditions. If a person's stress level is high, then a man will make the shift to meet their needs. In other words, someone migrating to other areas that have a usefulness or piece utility lower into areas that have a higher usefulness in regions where the needs are met. (Mantra, 2004).

According to Lee (1976 in Mantra, 2004), the migration process is influenced by several factors: (1) individual factors, (2) the factors contained in the regions of origin, (3) the factors contained in the goal area, (4) barriers between regions of origin and destination. Thus, the rural-urban mobility and reflects an imbalance in these two areas. Therefore, the direction of movement of residents of the city also tends to have large forces that are expected to meet their economic needs. Although that case, other factors that may cause migration as a factor of distance, cost, and information obtained. The distance factor and the cost as a whole because of the advances in the field of transport, the distance is already a function of money or costs.

The migration process of Bugis ethnic to Kupang is a migration phenomenon against the background of various things like interviews of informants below:

\subsubsection{RK informant}

The researcher interview with informant: RK, address of RK's workplace in Presidential Market Naikoten I Kupang, on 15th December, 2014 at 11:00 PM stated that:

..... I went to Kupang in 1990 and participated with my friend to change the fate with skills of a tailor in Bone and after arriving in Kota Kupang, I continued my work as a tailor. Alhamdulillah, with persistence and patience I managed to send my child in Bone until college. While my income every month, Alhamdulillah, it is enough to support my wife and three children, and even I could buy a house and a car for my wife and child in Bone. And then the Kiosk rent is very cheap only Rp. 3,000,000 per year. (Interviewed on 15th December 2014 at 11:00 AM).

The result of interview with RK above can give an idea that according to Lee (1966), Todaro (1979), Mantra (2004), argues that the motivation for someone to move is economic motives. The motive develops because of the economic disparities between regions. Todaro called the main motive as rational economic considerations. Urban mobility has two hopes namely, to get a job and earn an income higher than in the countryside. Rural-urban mobility also reflects an imbalance between the two areas. Population movements also tend to cities with higher opportunity to fulfill the economy needs.

It is in line with the findings of Tamar (2007), the value of local culture serves as a dynamic factor to the success of Bugis entrepreneurs, spurring their zeal to compete in conducting business activities that allow them to succeed. The seven values as follows: for Bugis, work hard (reso) is a way to maintain siri '(dignity). In working constantly determined (getteng) to finish the job. During the work continues to maintain the norms (lempu) and trying to find an alternative finishing work intelligently and creatively (acca). After all the effort (reso) is done; and then surrender to God, but he believes that fate of God will not come without effort. After succeed, he enjoyed to spend appropriately (asitinajang) and partly used to sympathize other relatives (pesse '). 


\subsubsection{Informants UM}

On tenth December, 2014, at 11:00 AM, the researcher interviewed UM, the age is 26 years old, profession as a trader, address: street Tempelo, Kupang, since 2010 migrated to the city of Kupang. The researcher asked to UM about the process of migrating to the city of Kupang.

UM replied: I went to Kupang because I was invited by my wife's uncle, and then in the early departing Um bring capital IDR 25 million for start-up capital, UM told that there were several times to move to sell at the beginning of his arrival, till he got a great place. UM told that his spot now 0 is pretty good income reached to Rp. 2 million to Rp. 3 million. It means that UM can save money every day Rp 200 thousand to Rp. 300 thousand with monthly income between 6 million to 9 million rupiahs. Whereas, the rent is only 7 million rupiahs annually. The researcher also asked "Is UM often go home?" UM answered: every Eid with his family, they return to Bone by plane, UM continued the story that he ever return for six in the village, because UM has a permanent home in the village with the results of operations in Kupang but his wife did not like at home in the village without any money. Finally, UM agreed to return to Kupang. (Interviewed on 10th December, 2014, at 11:00 AM).

\subsubsection{Informants H.AB}

The researcher asked about departure to Kupang, H.AB answered: I came in Kupang joined with brother to sell in the Inpres market, Naikoten I, Kupang.. H.AB came in Kupang in 1990, H.AB has a standalone now (stall) in the Inpres market and has a home to stay, H.AB pilgrim with wife. H.AB has four children. The researcher asked about earnings, H.AB answered: it depends on how many buyers between 2-5 million rupiahs per day and even more in the feast. The researcher asked whether the H.AB pay market tax. He said there is market tax but it is cheap, one day for 1,000 rupiahs and 50,000 rupiahs for a month. H.AB told that at first, her brother did not like in Kupang but finally he likes to work there, H.AB's brother has succeeded and his wife and children already stayed to Kupang. (Interviewed on 27th January, 2015)

The migration process and the success of H.AB in Kupang is inseparable from the role of older brother who was already successful in Kupang. Thus, brother and friends are very influential on the migration process and the success of someone like the description of Bourdieu (2000) cited in Turner (2012) that Sociology-Economy focuses on network approach, and the construction socioeconomic, using the concepts of habitus, sphere, interest and capital. Bourdieu argued that how people live their lives as part of the economy to struggle with and against the existing economic structure. In line with the research of Brown (1994), in Thailand about the behavior of discriminated minority groups. The success of the minority traders of Bugis ethnic was because of enabling the ethnics as a means of ethnic social to construct social solidarity, form a group of South Sulawesi Family Harmony to strengthen their network. The task of the group is to accommodate and assist new Bugis ethnic to open a business with the help of trade goods as desired.

The results of interviews with the informants above that migration to Kupang because in the region village (Bone) is hard to make money and work just as farmers, the income is not enough to live and other needs like building a house, expenses for wife and children, new marriage, thus decided to look for a new life and participate with uncle of his wife who success in Kupang.

Based on finding of Mantra (1999), mentioned that some theories that reveal why mobility is the theory of needs and stress. Every individual has some kind of economic needs, social, cultural, and psychological. If the demand is greater and cannot be met, the stress will be greater. When the stress already exceeds the limit, then someone will move to other places that have a usefulness value of the fulfillment of their needs. The development of the migration theory is known as the model of stress-threshold or place-utility.

Nevertheless, as mentioned earlier, according Revisten (1885), Thomas, Stouffer (1940), Lee (1966), Norris (1972), Mobolngunje (1970), and Mantra (2004), briefly, behavior of population mobility called as legal-migration, where the migration law is determined by some factors namely the most dominant factor affecting a person to migrate is the difficulty of obtaining work in the area of origin and makes it possible to obtain employment and better income in the goal area. Destination area must have benefit values (place utility) is higher than the original area. News of relatives or friends who have moved to other areas is very important information for people who want to migrate (Lee, 1885 in Mantra 2004). If the city influence is higher, then the mobility will be higher. In line with the opinion of the experts above, it shows that according to the findings of Bugis ethnic, migration to Kupang is much involved by following family and friends experience to migrate to Kupang.

Bourdieu (2000) cited in Turner (2012) Sociology economy focuses on network approach, economic and social construction, using the concepts of habitus, sphere, interest and capital. Bourdieu argued that how people live their lives as part of the economy that are struggling with and against the existing economic structure. Referring to research Brown 
(1994), in Thailand the behavior of discriminated minority groups. The success of the minority traders of Bugis ethnic because of enable ethnics as a means of ethnic social construct of social solidarity, form a group of South Sulawesi Family Harmony to strengthen their network. The task of the group is to accommodate and assist new Bugis ethnic to open a business with the help of trade goods as desired.

In the research of Endang Rudiatin (2012), about the economic integration of migrants in the village characterizes business relationships intertwined with the relations of kinship, friendship and ethnicity. Economic behavior is identified, namely, the old relationship between buyers and sellers is part strategy and security risks and comfortable in transaction, long-standing relationship in which the social network is also related to social, politics and religion relationships. All the networks that participate in economic activities, tied to loyalty and trust. The bond is attached to the base of kinship, friendship and then the bond is to determine the stability of the economic networks of Bugis ethnic. Economic networks of various kinds of trade, not only by commodity alone but also by ethnicity.

\subsection{Proses changes Bugis ethnic economy and contribute to the economy of the city of Kupang}

In line with the findings of researcher on contribution of Bugis ethnic to the economy of Kupang is very significant with BPS data in Kupang, source: www.kupangkota.go.id. Bugis ethnic in Kupang is about 6652 people working as a majority of traders and businessmen; it can contribute to the economy of Kupang. Economic contribution to the Bugis ethnic needed professional management by local governments, because there are many traders of Bugis ethnic have not been taking care of a business license letter and business place license letter due to the difficulty of various administrative requirements. In order to know the findings of researcher, there were interviews between the researchers with informant below with three social classes Bugis ethnic migrants in Kupang as follows:

\subsubsection{Elite class}

Bourgeoisie class is the class of the migration of successful Bugis ethnic in the business of trading such as large traders, entrepreneurs, wholesalers and forth as researchers' interview below:

a. Informants BK

BK's journey by ship from Makassar to Kupang using the KM Bukit Siguntang, accidentally, the researcher met BK, age 32 years old and work as trader:

informant ... .. BK told about the journey so long to Kupang, and told about the failure and success. BK told about the round trips of Kupang-Makassar each week by using a ship that carrying goods such as cloth gloves, bedding, shoes and sandals with a minimum purchase of Rp. 100 million to Rp 500 million. Then the researcher asked whether BK is selling alone or have subordinates? BK said: there are 10 subordinates in Oesao, every Friday BK went to Oesao to take the money, the amount of money depends on the provision, it is about Rp. 10 million, while the salaries of subordinates according to BK were not paid but every item was given a basic price, so the subordinates can sell over the base price as the profit of subordinates, while the net income every month \pm Rp. 30 million. BK proceedings in his speech of 2006 I was selling around in all districts in Southeast Nusa, ranging from Kupang, Rote, Sabu, the whole island of Flores, and Sumba. BK told about the bankrupt that cannot pay debt at the boss, now Alhamdulillah l've bought a house, selling place and accommodate the goods. (Interviewed on 19th November 2014)

b. Informants AM

And then the researcher interviewed the informant AM, Saturday on 27th December, 2014 at $06.00 \mathrm{am}$, at the time of the morning at Nostalgia Park, Kupang, AM stated that:

Go to Kupang in 1974, AM told about the first time went to Kupang come with AM's brother in Kupang. AM told about the journey in Kupang in 1974. AM told the first trip to Kupang began with AM's brother. AM was independently and several times move to other places. Am told about the experience in 2000s, AM bought land in the mayor, after building a new home and a place to sell sustenance feel better and could pilgrimage with parent in law (wife), and AM cand buy a car, now AM is no longer guard the store, only parent in law (wife) with children who watch, AM told that beta (I) just charity, and ask for forgiveness to God, because I had an easy time naughty, so now I pray, and to pray to God for mercy and charity to provision the Hereafter.

AM told that at the time of Haij, AM said in Mecca is often invited a fight by the people, AM told about the first time was easy fights in Kupang said AM rewarded by God in Mecca. AM further told the researcher that in AM's house is kake'e ( miser) when eating never scolds people, so in Mecca often cannot eat, this is the reply of God. AM then continued the story in Madina been lost because of the way arrogant, AM told to parent in law (wife) that I will not be 
missing here (Madina), briefly, AM went to pray in the mosque of Medina and cannot go back to the first place because AM see the mosque door looks all the same.

The result of interviews with the bourgeois class above shows that the essence of capitalism is competition possession, and rationality. In contrast to feudalism in which capital and sources of class formation depends on the ownership of land area and tradition, the source of difference capitalism and class divisions are capital and industrial capital holdings. The era of capitalism, the working class orientation is not the development of loyalty to the patron who protects the local elites who act as local authorities, because they tend to be alienated proletariat and experience the process of exploitation Yag cause their position really marginal. Labor relations between employers and workers in the era of capitalism are not built because of understanding and social solidarity, but rather because of necessity. The workers generally work because of the desire and need to be rewarded, and they tend to be powerless because of the developed dominance and hegemony of the bourgeois class with subordinates (Suyanto, B. 2013).

Marx considered the subordination of the working class and the bourgeoisie is the most important character of capitalism, because the position and the way that the bourgeoisie will be able to freely absorb the added value (Suplus value) of the workforce. Bargaining position is weak, the proletariat will often vulnerable to exploitation of the bourgeoisie or the owners of capital will continue to increase profits by minimizing expenses. This context is not wrong to say the new capitalism actually called capitalism when the heart of his life, namely the rationalization on sustainable income through the exploitation of labor, enters shutter community production (Suyanto B, 2013).

Capitalistic system, divided into two different types, namely the value (use value) and exchange rate (exchange value). Value for an item is the value of the goods benefit or benefits provided by an item when the item is used. The exchange rate is the value of an item that is obtained when the goods are exchanged for other goods. System of modern capitalism, the production of large number of items aimed primarily at exchange value, to earn some money as profit into capitalism strength for the goods they sell to the market. The capitalist system, the production of goods carried for sale to the market, and opened it for their own consumption (Suyanto, B. 2013).

The fundamental essence of capitalism, according to Robert Lekachman and Borin Van Loon (2008; 3), cited Suyanto B. (2013), among others: (1) Capital is part of the wealth of a nation Yag is a man's work and therefore can be produced repeatedly time (reproducible); (2) the system of capitalism, a society of capital equipment, the tools of production are owned by a handful of individuals who have a legal case for the use of his property in order to reap personal gain; and (3) of capitalism depends on the market system, which determines the distribution, allocating resources and determining the level of income, salary, rent expenses, and profit from social classes are different.

The fundamental essence of capitalism, according to Eric Wolf (1990: 77-90) quoted Suyanto (2013), mentions three main characteristics that marked capitalism. First, the growing wealth of the capitalist class that money can buy labor and production facilities to manufacture merchandise in the marketplace. Second, the capitalist class controls all means of production that are important in the economy of the community and restrict the free access of workers to the means of production, so the worker must sell their labor power to the capitalist. Third, the maximization of profit through the production of controlled entirely by the capitalist.

Meanwhile Ernest Mendel (2006), in more detail proposed five fundamental feature of capitalism, quoted (Suyanto, 2013). First, at the level of production, is the capitalist mode of production of commodities, namely production that sells all the results to the market to reach maximum profit. The production of commodities is a buffer through which the capitalist economic viability capitalists derive more value from the proletariat, and the value of commodities produced. Second, the production is based on private ownership of the means of production, that is, the power set strength productive- means of production and labor - not the collective property, but private property, whether it is personal interests or the group's financial authorities. Thirdly, the production run for an unlimited market, and is under the pressure of competition. Every capitalist attempted to receive the profits that can be dredged from the market. Therefore, each capitalist compete with other capitalists. Fourth, the production goal is to maximize profits. The ability to compete which led to the ability to make profits as much as possible requires the capitalist to sell commodities at a lower price than its competitors. Capitalists must expand its production network, so as to produce more commodities. The most efficient way is to increase the ability of its machinery, which is generally expensive, so to comply, the capitalist would not want to maximize profits by developing production as much as possible. Fifth, capitalist production is production for capital accumulation. Capital requires a majority of more value collected for poured back into productive activities. The surplus values taken translate into additional capital in the form of machinery, raw materials and additional manpower.

Capitalism, the ownership of the means of production is generally formal absolute. Someone cannot cultivate or involved in the processing of land, though legally recognized as the owner of these shares. The capitalist system is the only way for everyone to get the goods and services that have been produced which go to the market and to exchange his money with the goods. Likewise, a person in need of money, then he should go to the market and bring her 
belongings to be traded in the market, Muyanto $(2012 ; 18)$.

Bugis ethnic in Kupang is one of the ethnics that portray Mulyanto theory above, where Bugis ethnic assume the market is a fundamental institution in capitalism that allows the exchange process. Bugis ethnic make the market as a social institution that organizes social networking exchanges on the basis of supply and demand.

The economic system of capitalism has been subjected to various changes and adjustments in accordance with the demands of the times. Form of capitalism earliest production is what Marx called as manufacture industry, where a number of craftsmen work at a company with specialization and division of labor is quite complicated, but effective. Different premises of traditional economic activities are often inefficient, in the capitalist economic activity, which develops generally in work machine, where the labor began to be replaced by machines.

According to Adam Smith quoted Suyanto, Bagon (2013), capitalism, and drive productivity. Free market economy is believed to provide positive benefits, especially if the state does not interfere with restrictions. The capitalist system, principles developed by laissez faire (let it act alone), but according to Smith will create capitalism thrive benefit the community because it is controlled by Invincible hand (hand visible) which naturally regulate the balance between freedom and necessity (law of supply and demand).

\subsubsection{Middle class}

a. Informants $M \cdot A B$

Researchers interviewed M.AB, age 20 years old, live in Oesapa, Kupang, the researcher asked how long M.AB in Kupang? M.AB replied:

..... I am 20 years old and bring the goods to the capital, as well as bring the family while the place / home of their own, producing dirty every day between $R p .5$ million to $R p .10$ million while net income per month M.AB states between $R p$ 10 million and Rp 20 million. Then the researchers asked how levies market day? He replied between Rp. 1000 Rp. 5,000, whereas a business license tax and business licenses annually Rp. 250,000 to Rp 350,000. Researchers asked the status of ownership of business premises AB. express one's own Alhamdulillah has several places in the city of Kupang, including a residential house in Jln. Pharmaceutical Penfui Kupang.

Researchers asked about the relationship with the community (people Kupang) AB stated either as long as I exist in Kupang, there is only a small competition among traders, it is common place among merchants, fellow ethnic rivalry happen.

\section{b. Informants RK}

Further interviews RK on 15th December, 2014 at 11:00 AM, and RK told me about RK's family illustrates that let me (RK) stated that it:
... Study Only 3 SD (grade three is not finish) but RK determined to send his three children to college, RK said that children is the responsibility of parents to educate and meet their needs. Then RK talked for ten months a year ago Rk can collect money from sewing as much as Rp. 80 million, then RK pulled a cigarette and burn then sucked through the smoke billowing as he continued his story before arriving at RK Bone tells the story of the old car and buy a new car sells brand X-oper metik secen in 2012 at a price of Rp. 150,000,000 for his son who was studying in STIKES Bone and RK said one semester longer the child will be a midwife with PTT contract.

After I told him about the vagaries of his journey, RK proudly stated that people look at my work tailor so no one believed my income such as members of Parliament / esalon I, even proudly states that his son often asked by his professor on campus about the work of his father, finally RK also ending to my story with as many guests dating bring clothes to be sewn, and then I leave home and Belau asked when I come again, and I say Inshallah later when I have time to visit.

c. Informant H.LM.

The researchers interview on $20^{\text {th }}$ December, 2014, with uncle H.LM. about the process of departure to Kupang, he replied:

.....When I joined the family, I do not know su (already) long not remember lai (again). The researcher asked about the store, H.LM answer it was my shop, and two plots next, two plots that I rented to people with per square with price of 50 million per year, sumau (already completed) out of contract (again). 


\title{
d. Informants H.ST
}

The next day the interview on 20th December, 2014 with H.ST, age is 30 years old, live in Inpres market, Naikoten I, the researcher asked about the process of departure to Kupang, he replied:

\begin{abstract}
... . I accompanied with my uncle and I work in uncle as subordinate to sell in his shop, then a few years, I marry the child's my uncle, after the father-in-law (law) passed away, I took over the business with my wife. Now the shop-in-law, I leave to the brother-in-law because I've got my own shop, while the income between Rp. 5-10 million per day, while the net monthly income of between Rp. 5-10 million.
\end{abstract}

In line with the above study, barayen Becker Gary S. Turner (2012) looked at the economic sociology as the study of non-economic phenomena with the help micro-economy. In other case, Boltanski and Thevenot (2006) cited by BS Turner (2012) that the economic actors to develop what is called a conversion, as part of efforts to coordinate economic measures, conversion establish a standard way of thinking about reality and give reasons why action should be done.

The results of interview with the informant in middle class of Bugis ethnic above, then the researcher can give an idea that capitalism merchant of Bugis ethnic in Kupang is still traditional and still controlled by large capital owners, thus according to Weber capitalism is a value or mental attitude for profit rationally and systematically or a system of production-oriented quest for profit. Capitalism, according to Marx is also a mode of production and the relationship with the production process, which is led by implication in the context of the political economy, social psychology and cultural. When feudalism began to fade, and then present capitalistic economic system, then what happens then is the relationship between social changes in people's lifestyles.

\subsubsection{Retailers class (bottom)}

The researcher interviewed on 5th January, 2015 by Mr. NM. address: Osapa RT 27 RW 10, occupation: Fishermen, age is 40 years old. NM is asked by the researcher about the departure from Bugis to Kupang, Mr. NM replied:

a. Informan NM

... .. I came to Kupang because of own desire but I was with friends who had long lived in Kupang, I've been happy here because making money is more tolerable than in Bugis, the researcher asked whether NA bring capital? NA replied: at that time I bring capital of $R p 5.000 .000$, - when compared with the present value of 50 million, the number of people in the house 6 people, while a residence was still a contract with a price of Rp. 3000.000 / year, the researcher asked how the relationship between the local population in Kupang, NA said is well like brothers, whereas the competition problems are common in the business world, including my work as fishermen and fish sellers but do not have a negative impact as usual.

\section{b. Informant T.H}

The researcher interviewed on $4^{\text {th }}$ February, 2015, TH from Oesapa peaceful street, Age: 27 years old and occupation: merchants and fishermen. The researcher asked the arrival in Kupang, TH. States:

\begin{abstract}
... The arrival in Kupang do not know exactly because I was aged 13 at the time, I was joined by parents, now I'm married to have one child, the researcher asked whether the place is contracted / property itself, TH This place belongs to their own states, while earning between Rp.100.000-500.000 per day, the researcher asked how the relationship with the Kupang, TH, expressed either no problem might also accept us as newcomers very well even as your own, while the prices of goods and competition problems subscription. (Interviewed on 4th February, 2015).
\end{abstract}

\subsubsection{Informant ANW}

In the same day, $4^{\text {th }}$ February, 2015, the researcher interviewed ANW, age is 50 years old, address at Oesapa Beach, and occupation as merchant. The researcher asked the arrival in Kupang, ANW replied:

I came across a new Kupang about 2 years, the house still contract Rp. 7,000,000 per year while earning a hefty Alhamdulillah between Rp.1000.000-2000.000 / day, my Kupang to my son and my wife's family, while the market levy Rp.1000 / day permit businesses Rp 150,000 / year and place of business Rp. 150,000 / year. The researcher asked how the relationship with the Kupang, he said very good, I had 2 years in Kupang, but it seems to me the old man on the beach because everyone already knows me, including the original kuapng, while the issue of competition pack ANW. Personally never felt as everything is good. (Interviewed on 4th February, 2015) 


\title{
4. Contributions of Bugis ethnic For Kupang Ethnic
}

Kupang city development is very rapid because of the large share of Bugis ethnic in developing traditional markets, increase local revenues and employment of Kupang ethnic in various sectors of the efforts of Bugis ethnic in Kupang. Informant interviews with one of people Kupang ethnic, researchers in the field of Bugis ethnic stated contribution to the economy of the city of Kupang is very large, such as interviews with YN. YN, people of Kupang ethnic, 22 years old, stated that:

\begin{abstract}
Bugis ethnic presence in traditional markets Kupang greatly contributes to the economy of the city of Kupang, facilitate public / Kupang ethnic to buy daily necessities, developing traditional markets, enliven the market, increased revenues ethnic Kupang. Kupang ethnic happier shopping in the market traditional, compared to the modern market, so the community / Kupang ethnic prefers market traditional, although there is a mall, while the contribution of Bugis ethnic against the Kupang very much like using ethnic Kupang employee / shopkeepers, employees in the company, crewmen boat, public transportation drivers, a personal driver. (interview dated December 2, 2014)
\end{abstract}

Researchers interviewed a Kupang ethnic on December 2, 2014, initials VR.L. , Inquire about Bugis ethnic contribution to the economy of the city of Kupang. VR.L replied: Bugis ethnic many developing traditional markets, building a shop, build a mini market, develop new areas, developing a modern fishing, employing Kupang ethnic as labor in the store, the fishermen fishing uses bagang, in the company, including economic contribution helps increase revenue Kupang ethnic.

Furthermore, on the same day, researchers interviewed JN. She is one of Kupang ethnic, on the economic contribution of the Bugis ethnic for the city of Kupang. JN replied: "Bugis ethnic in market instruction, oeba market, Oesapa market, greatly contributed to the city of Kupang, especially the development of the market, the economy, the development of the city of Kupang and absorb labor of Kupang ethnic in minimarket, fishing effort Bugis ethnic and improve labor income for Kupang ethnic who work with Bugis ethnic. One of the economic contributions to the mutual benefit of Bugis ethnic, Bugis ethnic needs a land to build the store for business and otherwise Kupang ethnic need money for various needs.

Researchers also interviewed VB about contribution of Bugis ethnic to the economy of the city of Kupang. VB derived from Kupang answer: the ethnic Bugis much to contribute to the economic development of the city of Kupang, especially the traditional market, we know from the first market Instruction, Oeba market, Oesapa market, still quiet. However, after Bugis ethnic existed, the development of the market is very developed and developing, all requirements / needs prepared at an affordable price, while the economic contribution clear as retribution markets every day, the payment of business licenses, payment of license place of business, payment of property taxes increases revenue (PAD/Pendapatan Asli Daerah) Kupang.

\section{Conclusion}

1. The main factor that led to the Bugis ethnic in migrating to Kupang is because of family invitation, for economic reasons, better livelihood, cannot thrive in the wetland area because more narrow, not enough earnings for the family.

2. The economic development of Bugis ethnic migrants in Kupang very significantly contribute to the development of traditional markets in the city of Kupang. In line with the opinion of Polanyi et al (1957), Dalton (1961), Granovetter (1985), analysis of anthropological and sociological stressed market in the survival patterns of social organization and cultural significance, namely, economic behavior is not analyzed as a human activity that stands alone, but as inseparable from a wide variety of social, political and cultural, behavioral, institutions, and beliefs. An economic action has a strong delay in the context of social networks. Research Geetz Clifford (1977), on the market is an economic institution at once a way of life, a common style of economic activity that includes many aspects. The market is an entity that is not merely economic and sustain for the people's economy by bringing together sellers and buyers. Markets have responsibilities and functions are much more complex. The market becomes the arena of meeting various people's behavior, various shades of livelihood, trade, religion, immersive social system in the unity of ideas and activities. Sociologist interests towards the market, of course partially different from the concern of economists in the market, though certainly overlap with their concentration (economy). The term the market can bring a difference of meaning. 


\section{References}

Abustam. (1989). Population Movement, Development and Social Changes. (Thesis). Universitas Indonesia Press.

Anonim. (2011). Research Method: Quantitative, Qualitative and R\&D. Bandung: Alfabeta.

Anonim. Kupang Government. Retrieved from: www.kupangkota.go.id (accessed on 9th September 2013).

Anonim. Retrieved from: http://www.petantt.com/kota-kupang/ accessed on 17 March 2015.

Anonim. Retrieved from: http://www.petantt.com/kota-kupang/, accessed on 17th March 2015.

Castell Manuel. (1976). Theory Ideology in Urban Sociology in A Paper sociology in Urban Sosiologi. Critical Essays. Palgrave: Macmillan.

Creswell, J. W. (2009). Qualitative Inquiry and Research Design. California: Sage Publications. Inc.

Creswell, J. W. (1994). Research Design, Qualitative and Quantitative Approaches. Sage Publication.

Endang Rudiatin. (2012). Local Economic Integration in Frontier. (Dissertation). Jakarta: Postgraduate Program of University of Indonesia.

Furnivall. J.S. (2009). Dutch East Indies Economic Studies Compound. Jakarta. Fredeom Institute.

Geetz Clifford. (1977). Occupiers and King: Changes in Social and Economic Modernization in the Two Cities in Indonesia. Translated by S.Supomo. Jakarta: Badan penerbit Indonesia Raya.

Grenovetter, M. (1982). Economic Action and Social Structure: The Problems of Ambeddedness. American Journal of Sosiology, 91(3), pp 481-510.

Lee. E S. (1970). A Migration Theory. Translation series No. 3. Yogyakarta: Research Center Of Population Study of Gajah Mada University.

Lee. Martyn J. (2006). Consumer culture Reborn: New Directions Modernity in the study of Capital Consumption and Culture. Yogyakarta: Kreasi Wacana.

Lekachman., \& Borin van Loon. (2008). Capitalism: Theory and History Development. Yogyakarta: Resist Book.

Mantra, Ida Bagoes. (1999). General Demography. Yogyakarta: Nurcahaya Indonesia.

Moore, Wilbert E . (1974). Social Change. (2nd Ed.). Prentice-Hall Foundation of Moderns of Sociologies Series.

Polanyi, Karl. (1968). Anthropology and Economy Theory in Morton Fried Readings in Anthropology. New York: Thomas Creswel Company.

Popkin Samuel. (1979). The Rational Peasant: The Political Economy of Rural Society in Vietnam. California: University California Press.

Ritzer. (2011). Sociological Theory, From Sociology Classics Until Postmodern. (8Th Ed). Yogyakarta: Pustaka Pelajar.

Sugiyono. (2011). The Combination of Research Methods. Bandung: Alfabeta.

Suyanto.B. (2013). Economic Sociology of Capitalism and Society Consumption in the Era of Post-Modernism. Jakarta: Pranada Media Group.

Sztompka Piotr. (2011). Sociology of Social Change. Translated by Alimadan. Jakarta: Pranada Media Group.

Tirto Sudarmo. (1993). Bugis Migration to Samarinda, east Kalimantan. Eastabilishin a Colony in Horizon of Home. Nation Gender and Migracy in Island Southeast Asia. Penelope Graham. Moulbourne:. Monash Asia Institude.

Turner. (2012). Theories of the Classic Social in Post Modern translated by E. Setiawaty A. and Roh Susiaty. Jakarta: Pustaka Pelajar.

Tamar, Muhammad. (2007). Influence of Local Cultural Values System of the motivational value types and properties of Successful Entrepreneurs Entrepreneurship in Bugis. (Studies on Small and Medium Enterprises in South Sulawesi). (Dissertation). Jakarta: Faculty of Post Graduate UI.

Wirawan, Ida Bagus. (2006). Migration Secular Of Employee Women To Abroad: Study Of Decision Making Migrate By Rural Woman in Java. (Dissertation). Postgraduate Program of University of Airlangga Surabaya. 